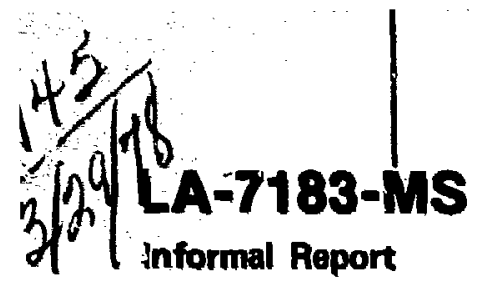

th. 1958

UC-20d

Issued: March 1978

\title{
RIGGATRON Nucleonics: \\ One-Dimensional Analysis
}

\author{
B. R. Wienke \\ Donald J. Dudziak \\ G. E. Bosler
}

G. E. Bosler 
NOTICE

This repurt ons prepared as an secount of work sponkased by the United Suates Goverument. Neither the Ened States not the Unired States Depurtment of Energy. nor any of thetr employees, not sny of their contsactars, subcontractors, of their employees, makes any warranty, express or inplied, or ansumes iny lega liability or responsibulity for the aceuracy, completenen or usefulness of any information, apperatus, product or reocess diselnsed, or repre. th that ith ure would not infringe privately owned rights.
Donald J. Dudziak and

G. E. Bosler

ABSTRACI

Results of $S_{N}$ and Monte Carlo une-diriensional neutron/gamma-ray transport calculations for conceptual desizns of the INESCO RIGGATRON, a Tokamak device using ohmic heating to induce fusion, are detailed. Using various plasma, col1, and blanket configurations, a comparative analysis of cross-section sets is first performed. Scoping calculations of tritiun breeing rat1os, absorptions, leakages, and neutron/ gamma-ray heating are detailed using both multigroup discrete-ordinates and Monte Carlo techniques. Results of this analysis not only serve to provide preliminary design parameters, but also indicate relative degree of consistency among various cross-section sets. Consistency between $S_{\mathrm{N}}$ and Monce Carlo techniques is similarly demonstrated. Results of this one-dimensional compilation also guggest a two-dimensional RIGGATRON model for related study.

I. INTRODUCTION

We have undercaken a sertes of one- and twodimensional neutron/gamma-ray transport calculations for the INESCO RIGGATRON, a small Tokamak device employing high field, ohmic heating to induce deuterium-tritium fustion. As seen in Fig. 1, the RIGGATRON consists of a small, offcenter, D-T plasma zone surrounded by essentially concentric vold, copper coil, lithium blanket, and graphite reflector regions. of conceptual design incerest are the blanket tritium breeding ratios, [1.e., ${ }^{6} L i(n, t) \alpha,{ }^{7} L\left(n, n^{\prime} t\right) \alpha$ ] leakages, absorptions, and neutron/gamma heating in vartous regions and matertais. In this report, we give only the results of a comparat Ive one-dimensional study of the RIGGATRON for various plasma, coll, blanket, and reflector configurations. Two-dimenstonal calculations are under way and will be reported later. The one-dimensional calculations were performed with the diffusion synthetic, $S_{N}$ cade, ONETRAN-DA, ${ }^{1}$ and the corresponding two-dimens mal calculations with the triangular mesh, $\mathrm{S}_{\mathrm{N}}$ code, TRIDENT-CTR. 2
One task conslsted of evaluation of various coupled neurron/gatura-ray cross-section sets and choice of an adequate file from among them to be

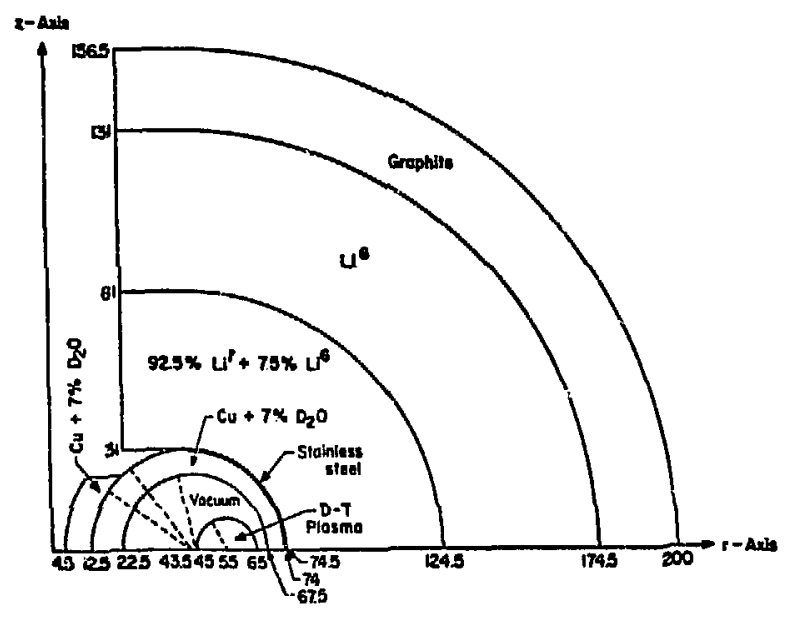

Fig. 1. Two-dimensional RIGGATRON (dimensions in $\mathrm{cm}$ ). 
used in subsequent one- and two-dimensional transport calculations. Libraries tested included the LASL-SAND $(30 \times 12)^{3}$ set, the CTR $(101 \times 21)^{4}$ set [collapsed from the VITAMIN-C $(171 \times 36)^{5}$ file], the LASL-NJOY $(30 \times 12)^{6}$ set, and the new MATXS $(30 \times 12)^{7}$ get. Cholce of the MATXS get was eventually made following overlapping calculations with other sets.

The actual one-dimensional mudels of the RIGGATRON Investigated varied in plasma, coll, and blanket: thickness. Additionally, effects of neutron multiplication $(n, 2 n$ reaction) in a molybdenum liner and coolant effects $\left(7 \% \mathrm{H}_{2} \mathrm{O}\right.$ and $\mathrm{D}_{2} \mathrm{O}$ in copper and molybdenum) on the breeding ratios, leakages, and absorptions were also noted. In further extension, a graphite zeslector was added and a vold Introduced between the coll and the blanket to enhance tritium breeding and reduce neutron leakage. Neutron and gamma-ray heating calculat lons were performed in the latter deaign cases. In all rases, an isotroptc 14-MeV source of neutrons was assigned to the plasma void region. An $\mathrm{S}_{8}$ quadrature set and $\mathrm{P}_{3}$ cross-section expansion were retained consistently for the one-dimensional cylindrical computations. Vacuum boundary conditions were assigned to the blanket or reflector edge and the usual reflective (symmetrical) conditions were applied at the origin. The neutron source in the plasma was normalized to unity.

As a cross check on the $S_{N}$ approach, a corresponding Monte Carlo calculation was completed for a set of plasma, coll, and blanket paraneters. Agreement between une-dimensional Monte Carlo and $S_{N}$ predictions of breeding and leakage is good, within four percent for the cases considered.

While one-dimensional cylindrical calculations provide good relative estimates of breeding, heating, leakage, etc. . they cannot express? $y$ account for toroldal geometric effects and asymatry in blanke. and coil design. For these reasons, a follownp two-dimensional toroidal $(r, z)$ calculation is presently under way using the $S_{N}$ triangular mesh coje, TRIDENT-CTR. ${ }^{2}$ The two-dimenstonal model of the RIGGATRON is shown in Fig. 1. Use of a triangular mesh greatly facllitates contouring of materlal and device boundaries. Our one-dimenstonal atudy does Inditcate feastble breeding ratios in excess of one, so that two-dimensional refinements are additionally warranted.

\section{CROSS-SECTION COMPARISONS}

Coupled neutron/gamma-ray cross sections were avallable from the LASL-SAND $(30 \times 12),{ }^{3}$ CTR $(101 \times$ 21), ${ }^{4}$ LASL-NJOY $(30 \times 12),{ }^{6}$ and MATXS $(30 \times 12)^{7}$ 1ibraries. The LASL-SAND $(30 \times 12)$ set is a number of years older than the other three and is based primarily on ENDF/B-II and ENDF/B-III data. The other three 1ibrarles were processed more recently, primarily from ENDF/B-IV data. Because of the $1 \mathrm{~m}-$ portance of tritium breeding in both ${ }^{6} \mathrm{LI}_{1}$ and ${ }^{7} \mathrm{~L}$, it was thought that the latest processed cross sections based on ENDF/B-IV evaluations would probably be most degirable, particularly for the 11thium. Since the extent of differences in the above $11 b$ raries was not immediately known, we performed groups of overlapping calculations for flxed RIGGATRON parameters in an attempt to evaluate overall library consistency.

In these comparisons, we fixed the plasma radius at $22.5 \mathrm{~cm}$, coll thickness at $10 \mathrm{~cm}$, and blanket (natural lithium) thlekness at either $100 \mathrm{~cm}$ or $0 \mathrm{~cm}$ (no blanket). Full dense and cooled $\left(7 \% \mathrm{H}_{2} \mathrm{O}\right)$ copper colls are also traated. Table I 11sts ${ }^{6}{ }_{\mathrm{L}}{ }^{2}$ and ${ }^{7}{ }_{\mathrm{L}}$ breeding ratios $\left(T_{6}\right.$ and $\left.T_{7}\right)$, neutron leakage $(L)$, and copper absorption ( $\mathrm{A}_{\mathrm{Cu}}$ ) computed with the LASL-SAND $(30 \times 12)$, LASL-NJOY $(30 \times 12)$, and CTR (101 $\times 21)$ coupled sets. Close agreement is seen in the predictions of the LASL-NJOY $(30 \times 12)$ and CTR (101 $\times 21)$ sets. Relative consistency between the three librarles Is good, with must differences occurring in the ${ }^{6} \mathrm{LI}$ breeding ratio, $\mathrm{T}_{6}$. Absorption cive to the water produces about a $20 \%$ reduction in the sum of breeding plus leal:age $(T+L)$ for all sets.

A second comparison of the GTR (101 x 21), LASLNJOY $(30 \times 12)$ and MATXS $(30 \times 12)$ cross-section sets was made with the same RIGGATRON parameters used in Table $I$, both for full dense and $\mathrm{H}_{2} \mathrm{O}$ cooled copper. The entrles have been rearranged to permit closer comparison. The overall consistency, as exhibited In Table II, Is excellent, with agreement within $5 \%$ for all cases. Strice these librarles all represent recent evaluations, agreement is reasonably expected.

The larger CTR (101 $\times 21)$ file would a:ford maximum resolution for these calculations, but this advantage comes at the expense of three to four times Increase in actual computing time. Use of the CTR (101 $\times 21)$ set in a two-dimensional calculation would 
TABLE I

CROSS-SECTION COMPARISON OF LASL-SAND (30 $\times 12$ ), LASL-NJOY $(30 \times 12)$, and CTR $(101 \times 21)$ SETS

\begin{tabular}{|c|c|c|c|c|c|c|c|c|c|c|}
\hline $\begin{array}{c}\text { I (Plasma) } \\
(\mathrm{cm})\end{array}$ & $\begin{array}{c}\Delta r \quad(\mathrm{Cu}) \\
-(\mathrm{cm}) \\
\end{array}$ & $\begin{array}{c}\Delta=\quad(\mathrm{LI}) \\
(\mathrm{cm}) \\
\end{array}$ & $T_{6}$ & $\mathrm{~T}_{7}$ & $\mathbf{T}$ & $\mathbf{L}$ & $\underline{T+\underline{L}}$ & ${ }^{A} \mathrm{Cu}$ & Coolant & LAbrary \\
\hline \multirow{3}{*}{22.5} & & & 0.714 & 0.118 & 0.832 & 0.191 & 1.023 & $\mathbf{a}$ & none & $(30 \times 12)$ \\
\hline & & & 0.801 & 0.126 & 0.927 & 0.252 & 1.177 & a & none & $(30 \times 12)$ \\
\hline & & & 0.640 & 0.138 & 0.778 & 0.182 & 0.960 & 0.507 & $7 \% \mathrm{H}_{2} \mathrm{O}$ & CTR \\
\hline \multirow[t]{5}{*}{22.5} & 10.0 & - & - & - & - & 0.917 & - & a & $7 \% \mathrm{H}_{2} \mathrm{O}$ & SAND \\
\hline & & & - & - & - & $1 . \pm 10$ & - & $\mathbf{a}$ & none & $(30 \times 12)$ \\
\hline & & & - & . & - & 0.884 & - & $\mathbf{a}$ & $7 \% \mathrm{H}_{2} \mathrm{O}$ & NJOY \\
\hline & & & - & - & - & 1.081 & - & F & none & $(30 \times 12)$ \\
\hline & & & - & - & - & 0.932 & - & 0.402 & $7 \% \mathrm{H}_{2} \mathrm{O}$ & CTR \\
\hline
\end{tabular}

${ }^{a}$ Comparative pure absorption crose sectlons were not available.

be prohibitive. Because of accessibility, timeliness and overall degree of consistency with earlier evaluations, we rely mostly upon the MATXS (30 x 12) neutron/gama-ray get for the bulk of the one- and two-dimensional calculations.

\section{CONCEPTUAL DESIGN COMPARISONS}

For initial analysis, six cylindrical RIGGATRON configurations consisting of a central D-T plasma, water cooled (77) copper coll, and molybdenum liner (neutron multiplier) and natural lithium $\left(92.5 \%{ }^{7} \mathrm{LI}\right.$ $+7.5 \%{ }^{6}$ L1) blanket were chosen. An 1sotropic source of 14-MeV neutrons, normalized to unity, was placed in the plasm. Vacuum boundary conditions were assigned at the blanket and reflecting boundary conditions at the orfgin. An $S_{8}$ quadrature and $P_{3}$ cross-section expansion were employed in the calculations. The LASL-SAND ( $30 \times 12$ ) coupled neutron/ gamma-ray set was used in this scoping compilation, shown in Table III, because it was most readily available at the time. The negative absorptions in molybdenum result from net neutron nultiplication via the $(n, 2 n)$ reaction. The corresponding cross sections, of course, are not pure absorption cross sections.
Although the molybdenum affords net neutron multiplication, it is clear from Table III that corresponding increases in copper and molybdenum absorption tend to offset both tritium breeding and leakage, particularly as the thickness of the molybdenum liner increases. The absorptions in both copper and molybdenum Increase with thickness. From Table I, one expects the breeding ratios given In Table III to be somewhat low. Nonetheless, Table III st111 provides a base line.

As an alternative to $\mathrm{H}_{2} \mathrm{O}$ as coolant, $\mathrm{D}_{2} \mathrm{O}$ absorbs fewer neutrons. Quantitatively, Tabie IV exhibits the comparative effects of using $\mathrm{H}_{2} \mathrm{O}, \mathrm{D}_{2} \mathrm{O}$, and no coolant in the copper coll and nolybdenum 11ner. As expected, significant decreases in absorption and increases in blanket breeding (10\%-15\%) are effected by substituting $\mathrm{D}_{2} \mathrm{O}$ for $\mathrm{H}_{2} \mathrm{O}$ as coolant.

Introduction of a vold between the coll and blanket concelvebly enhances the blanket reabsurption probability for neutrons initially backscettered from the blanket. Without a streaming void, a larger percentage of backscattered neutrons would be absorbed in the copper coll. To demonstrate this effect, a vold of 300 $\mathrm{cm}$ Is Introduced between coll and blanket. Table $V$ lists the corresponding predictions. Gains in the tritium breeding ratiog and logses in leakage are 
TABLE II

CROSS-SECTION COMPARISON OF GTR (101 x 21), LASL-NJOY (30 : 12 ), AND MATKS $(30 \times 12)$ SETS

\begin{tabular}{|c|c|c|c|c|c|c|c|c|c|c|}
\hline $\begin{array}{l}\text { I (Plasma) } \\
(\mathrm{cm}) \\
\end{array}$ & $\begin{array}{l}\Delta r(\mathrm{Cu}) \\
\quad(\mathrm{cm}) \\
\end{array}$ & $\begin{array}{r}\Delta \mathbf{r}(\mathrm{Li}) \\
\quad(\mathrm{cm}) \\
\end{array}$ & $\mathrm{T}_{6}$ & $\mathrm{~T}_{7}$ & $T$ & $L$ & $\underline{T+L}$ & $-{ }^{\mathbf{A}_{\mathrm{Cu}}}$ & Library & Coolant \\
\hline \multirow[t]{3}{*}{22.5} & 10.0 & 100.0 & 0.640 & 0.138 & 0.778 & 0.182 & 0.960 & 0.507 & $\begin{array}{l}\text { CTR } \\
(101 \times 21)\end{array}$ & \multirow{6}{*}{$\begin{array}{l}7 \% \mathrm{H}_{2} \mathrm{O} \\
\mathrm{CoI1} 2^{2}\end{array}$} \\
\hline & & & 0.637 & 0.132 & 0.769 & 0.182 & 0.951 & a & $\begin{array}{l}\text { MATXS } \\
(30 \times 12)\end{array}$ & \\
\hline & & & 0.638 & 0.135 & 0.773 & 0.182 & 0.955 & a & $\begin{array}{l}\text { NJOY } \\
(30 \times 12)\end{array}$ & \\
\hline \multirow[t]{3}{*}{22.5} & 10.0 & - & - & - & - & 0.932 & - & 0.402 & $\begin{array}{l}\text { CTR } \\
(101 \times 21)\end{array}$ & \\
\hline & & & - & - & - & 0.914 & - & a & $\begin{array}{l}\text { MATXS } \\
(30 \times 12)\end{array}$ & \\
\hline & & & - & - & - & 0.884 & - & $a$ & $\begin{array}{l}\text { NJOY } \\
(30 \times 12)\end{array}$ & \\
\hline \multirow[t]{3}{*}{22.5} & 10.0 & 100.0 & 0.760 & 0.128 & 0.888 & 0.257 & 1.145 & 0.325 & $\begin{array}{l}\text { CTR } \\
(101 \times 21)\end{array}$ & \\
\hline & & & 0.757 & 0.123 & 0.880 & 0.249 & 1.129 & $\mathbf{a}$ & $\begin{array}{l}\text { MATXS } \\
(30 \times 12)\end{array}$ & \\
\hline & & & 0.801 & 0.126 & 0.927 & 0.252 & 1.179 & $\mathbf{a}$ & $\begin{array}{l}\text { NJOY } \\
(30 \times 12)\end{array}$ & none \\
\hline \multirow[t]{3}{*}{22.5} & 10.0 & - & - & - & - & 1.119 & - & 0.231 & $\begin{array}{l}\text { CTR } \\
(101 \times 21)\end{array}$ & \\
\hline & & & - & - & - & 1.096 & - & $\mathbf{a}$ & $\begin{array}{l}\text { MATXS } \\
(30 \times 12)\end{array}$ & \\
\hline & & & - & - & - & 1.081 & - & $\mathbf{a}$ & $\begin{array}{l}\text { NJOY } \\
(30 \times 12)\end{array}$ & \\
\hline
\end{tabular}

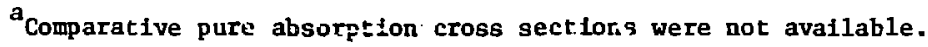

apparent. An overall gain of approximately $15 \%$ in the sum of breeding plus leakage is noted in both cases ( $7 \% \mathrm{H}_{2} \mathrm{O}$ coolant, no coolant).

Lasty, we consider the effects of a graphite reflector outside the blanket. The central plasma is now taken to be $22.5 \mathrm{~cm}$, the copper coll $7 \mathrm{~cm}$ and
$10 \mathrm{~cm}$ thick, the void $200 \mathrm{cml}$ thisk, the blanket 100 cm thick, and the graphlte reflector $25 \mathrm{~cm}$ thick. The $S_{8}$ quadrature and $P_{3}$ cross sections are again used from the MATXS file. Table VI gives the results, assuming $7 \% \mathrm{D}_{2} \mathrm{O}$ coolant in the cooper. Neutron $(\mathrm{n})$ and ganma $(\gamma)$ heating in the copper, lithium and

TABLE III

COMPARATIVE BREEDING, LEAKACE, AND ABSORPTION FOR RIGGATRON (7\% $\mathrm{H}_{2} \mathrm{O}$ COOLANT)

\begin{tabular}{|c|c|c|c|c|c|c|c|c|c|c|}
\hline $\begin{array}{l}\text { r (Plasma) } \\
(\mathrm{cm}) \\
\end{array}$ & $\begin{array}{l}\Delta r \text { (Mo) } \\
\quad(\mathrm{cm}) \\
\end{array}$ & $\begin{array}{l}\Delta r(\mathrm{Cu}) \\
\quad \text { (cm) }\end{array}$ & $\begin{array}{l}\Delta r(\mathrm{LI}) \\
\quad(\mathrm{cm})\end{array}$ & $T_{6}$ & $\mathrm{~T}_{7}$ & $\mathrm{~T}$ & $\mathbf{L}$ & $\underline{T+L}$ & Ao & ${ }^{A} \mathrm{Cu}$ \\
\hline 22.5 & - & 10.0 & 100.0 & 0.587 & 0.128 & 0.715 & 0.146 & 0.861 & - & 0.208 \\
\hline 22.5 & 2.0 & 10.0 & 100.0 & 0.550 & 0.094 & 0.644 & 0.127 & 0.771 & -0.075 & 0.343 \\
\hline 22.5 & 4.0 & 10.0 & 100.0 & 0.493 & 0.070 & 0.553 & 0.105 & 0.658 & -0.032 & 0.395 \\
\hline 22.5 & 4.0 & 15.0 & 100.0 & 0.240 & 0.025 & 0.265 & 0.060 & 0.325 & -0.015 & 0.619 \\
\hline 15.0 & 2.0 & 7.0 & 100.0 & 0.690 & 0.159 & 0.849 & 0.185 & 1.044 & -0.109 & 0.1 .64 \\
\hline 15.0 & 2.0 & 10.0 & 100.0 & 0.569 & 0.098 & $0.66,7$ & 0.138 & 0.805 & -0.090 & 0.326 \\
\hline
\end{tabular}


TABLE IV

COMPARATIVE BREEDING, LEAKAGE, AND ABSORPTION FOR RIGGATRON ( $7 \% \mathrm{H}_{2} \mathrm{O}, \mathrm{D}_{2} \mathrm{O}$ AND NO COOLANT; MATXS LIBRARY)

\begin{tabular}{|c|c|c|c|c|c|c|c|c|c|c|c|}
\hline $\begin{array}{c}r \quad(\text { Plasma }) \\
(\mathrm{cm}) \\
\end{array}$ & $\begin{array}{l}\Delta r \quad(M o) \\
\quad(\mathrm{ct}) \\
\end{array}$ & $\begin{array}{l}\Delta r(\mathrm{Cu}) \\
\quad(\mathrm{cm}) \\
\end{array}$ & $\begin{array}{l}\Delta r(\mathrm{Li}) \\
\quad(\mathrm{cm}) \\
\end{array}$ & $T_{6}$ & $\mathrm{~T}_{7}$ & $\mathrm{~T}$ & L & $T+L$ & $\mathrm{Ap}$ & ${ }^{A} \mathrm{Cu}$ & Coolant \\
\hline \multirow[t]{3}{*}{22.5} & - & 10.0 & 100.0 & 0.587 & 0.128 & 0.715 & 0.146 & 0.861 & - & 0.208 & $7 \% \mathrm{H}_{2} \mathrm{O}$ \\
\hline & & & & 0.658 & 0.128 & 0.786 & 0.172 & 0.958 & - & 0.097 & $7 \% \mathrm{D}_{2} \mathrm{O}$ \\
\hline & & & & 0.714 & 0.118 & 0.832 & 0.191 & 1.023 & - & 0.012 & none \\
\hline \multirow[t]{3}{*}{22.5} & 2.0 & 10.0 & 100.0 & 0.550 & 0.094 & 0.644 & 0.127 & 0.771 & -0.075 & 0.343 & $7 \% \mathrm{H}_{2} \mathrm{O}$ \\
\hline & & & & 0.649 & 0.095 & 0.744 & 0.158 & 0.902 & -10.127 & 0.248 & $7 \% \mathrm{D}_{2} \mathrm{O}$ \\
\hline & & & & 0.734 & 0.087 & 0.821 & 0.184 & 1.005 & -0.169 & 0.166 & none \\
\hline \multirow[t]{3}{*}{15.0} & 2. 1 & 7.0 & 100.0 & 0.690 & 0.159 & 0.849 & 0.185 & 1.034 & -0.109 & 0.164 & $7 \% \mathrm{H}_{2} \mathrm{O}$ \\
\hline & & & & 0.773 & 0.160 & 0.933 & 0.216 & 1.149 & -0.159 & 0.086 & $7 \% \mathrm{D}_{2} \mathrm{O}$ \\
\hline & & & & 0.828 & 0.150 & 0.978 & 0.236 & 1.214 & -0.159 & 0.038 & none \\
\hline
\end{tabular}

carbon are also 11 sced in the last six columns (MeV). Falrly large (greater than 1.10) breecing ratios are seen. The bulk of the neutron heating occurs In lise blanket, while most of the gamma-ray heating takes place in the copper coll. The neutron/ganuaray kerma factors account for both neutron/gammaray energy deposition. Effectively, in the two cases seen, graphite enhances breeding by reduction of leakage.

This one-dimenstonal study Indicates possib.le tritium breeding ratios in the nelghborhood of 1.10 , realistically using $D_{2} 0$ as coolant. Introduction of a vold space between the coll and blanket, and $a$ graphite reflector, considerably enhances computed breeding ratios. The calculations are sensitive to the thickness of the copper coll, presence or nunpreserce of $\mathrm{H}_{2} \mathrm{O}$ or $\mathrm{D}_{2} \mathrm{O}$ coolant, and thickness of nolybdenum multiplier. Plasma radil ranged from $15 \mathrm{~cm}$ to $22.5 \mathrm{~cm}$, copper coll thicknesses from $7 \mathrm{~cm}$ to $15 \mathrm{~cm}$, molybden:= liners from $2 \mathrm{~cm}$ to $4 \mathrm{~cm}$, and coll-blanket volds from $200 \mathrm{~cm}$ to $300 \mathrm{~cm}$. The blanker. thickness was fixed at $100 \mathrm{~cm}$ and the reflector thickness at $25 \mathrm{~cm}$.

\section{MONTE CARLO COMPARISOIS}

As an additional check on the cross sections as we11 as the discrete-ordinates calculational model, a continuous energy Monte Carlo calculation (MCNP code) ${ }^{8}$ was performed. This Mnte Carlo calculation duplicated the one-dimensional discrete-ordinates calculation for a $22.5-\mathrm{cm}$ radius plasma, 7-cm-thick copper coll, and a 1-m-thick natural Li blanket. All calculations of tritfum breeding and neutron leakage were performed to a relative standard deviation of $1 \%$. Table VII shows results of compart. sons among varlous cross-section sets, where the MATXS 11brary was processed from ENDF-IV. Here we have a direct comparison of the MATXs library with a calculation using its progenitor FNDF-IV pnintwise library. The compertson Inciudes errors due

\section{TABLE V}

COMPARATIVE BREEDING, LEAKAGE, AND ABSORPTION FOR RIGGATRON WITH VOID BETWEEN COIL AND BLAYKET ( $7 \% \mathrm{H}_{2} \mathrm{O}$, NO COOLANT; KATXS LIBRARY)

\begin{tabular}{|c|c|c|c|c|c|c|c|c|c|}
\hline $\begin{array}{c}\text { I (Plasma) } \\
\text { (cm) }\end{array}$ & $\begin{array}{l}\Delta r(\operatorname{Cot} 1) \\
(\mathrm{cm}) \\
\end{array}$ & $\begin{array}{l}\Delta r \quad \text { (Vold) } \\
\text { (cm) }\end{array}$ & $\begin{array}{c}\Delta \mathbf{r} \text { (blanket) } \\
(\mathrm{cm})\end{array}$ & $\mathrm{T}_{6}$ & $\mathrm{~T}_{7}$ & $T$ & $\mathbf{L}$ & $\underline{T+L}$ & Coolant \\
\hline \multirow[t]{3}{*}{22.5} & 10.0 & - & 100.0 & 0.643 & 0.135 & 0.778 & 0.182 & 0.960 & \\
\hline & & 300.0 & $10 \cap .0$ & 0.739 & 0.139 & 0.878 & 0.159 & 1.037 & $7 \% \mathrm{H}_{0} \mathrm{O}$ \\
\hline & & - & - & & & & 0.914 & & 2 \\
\hline \multirow[t]{3}{*}{22.5} & 10.0 & - & 100.0 & 0.757 & 0.123 & 0.880 & 0.248 & 1.129 & \\
\hline & & 300.0 & 100.0 & 0.874 & 0.129 & 1.003 & 0.205 & 1.200 & none \\
\hline & & - & - & & & & 1.096 & & \\
\hline
\end{tabular}


TABLE VI

COMPARATIVE BREEDING, LEAKAGE, ABSORPTION, AND HEATING FOR RIGGATRON WITH VOID AND REFLECTOR' $7 \% \mathrm{D}_{2} 0$ COOLANT; MATXS LIBRARY)

\begin{tabular}{|c|c|c|c|c|c|c|c|c|c|c|c|c|c|c|c|}
\hline $\begin{array}{r}\text { r (P1 asma) } \\
(\mathrm{cm})\end{array}$ & $\begin{array}{l}\Delta \mathrm{r}(\mathrm{Co11}) \\
(\mathrm{cm}) \\
\end{array}$ & $\begin{array}{c}\Delta \mathbf{r} \begin{array}{l}\text { (Void) } \\
(\mathrm{cm})\end{array} \\
\end{array}$ & $\begin{array}{c}\Delta \mathrm{r} \text { (Blanket) } \\
(\mathrm{cm}) \\
\end{array}$ & $\begin{array}{c}\Delta r \text { (Graphite) } \\
(\mathrm{cm})\end{array}$ & $T_{6}$ & $\mathrm{I}_{7}$ & $\mathbf{T}$ & $\mathbf{L}$ & $I+L$ & $Q_{\mathrm{Cu}}^{\mathrm{n}}$ & $Q_{\underline{c_{u}}}^{\gamma}$ & $Q_{L i}^{n}$ & $Q_{I_{1}}^{\gamma}$ & $\mathbf{Q}_{c}^{n}$ & $Q_{c}^{\gamma}$ \\
\hline 22.5 & 7.0 & 200.0 & 100.0 & 25.0 & 1.081 & 0.229 & 1.310 & 0.004 & 1.314 & 1.09 & 6.21 & 7.69 & 1.03 & 0.03 & 0.16 \\
\hline 22.5 & 10.0 & 200.0 & 100.0 & 25.0 & 0.969 & 0.139 & 1.108 & 0.003 & 1.111 & 1.34 & 8.55 & 6.22 & 0.75 & 0.02 & .13 \\
\hline
\end{tabular}

TABLE VII

COMPARISON OF MONTE CARLO RESULTS HITH DISCRETE-ORDINATES CALCULATIONS, FOR 7-im COIL (7\% $\mathrm{D}_{2} 0$ ) AND 1-m BLANRET $\left(\mathrm{n}_{\mathrm{L}}\right)$

\begin{tabular}{|c|c|c|c|c|c|}
\hline Calculational Method & Cross-Sect Ion Set & Lealiage & $\begin{array}{l}\text { \% DIfference } \\
\text { from Monte Carlo }\end{array}$ & $\underline{I}$ & $\begin{array}{l}\text { \% Difference } \\
\text { from Monte Carlo }\end{array}$ \\
\hline \multirow[t]{2}{*}{ Monte Carlo, MCNP } & ENDF-IV & 0.267 & - & 1.0974 & - \\
\hline & Pointwise & & & & \\
\hline \multirow[t]{2}{*}{$S_{8} P_{3}$, ONETRAN-DA } & LASL-SAND & 0.277 & 3.74 & 1.0545 & -3.91 \\
\hline & $(30 \times 12)$ & & & & \\
\hline $\mathrm{S}_{8} \mathrm{P}_{3}$, ONETRAN-DA & $\begin{array}{l}\text { MATXS } \\
(30 \times 12)\end{array}$ & 0.275 & 3.00 & 1.0565 & -3.73 \\
\hline
\end{tabular}


to more than just cross-section processing, such as those inherent in the discrete-ordinates approximation, and the statistical error in the Monte Carlo results. However, the net result in all cases agrees to within $4 \%$ for both tritium breeding and leakage. We thus adopted the $30 \times 12$-group MATXS library for al1 further multigroup analysis.

\section{REFERENCES}

1. R. E. Alcouffe, "Diffusion Synthet:ic Acceleration Methoda for the Diamond-Differenced Discrete Ordinates Equations," Nucl, Sci. Eng. 64, 344 (1977).

2. T. J. Seed, "TRIDENT-CTR Code Manual," (to be pub11shed).

3. H. A. Sandmeter, G. E. Hansen, R. E. Seamon, T. J. Hirons, and A. H. Marshall, "Coupled Neutron-Gamma Multigroup Multitable Cross Sections for 29 Materials Pertinent to Nuclear Weapons Effect Calculations Generated by LASL/ TD Diviston," Los Alamos Scientific Laboratory report LA-5137 (February 1974).
4. R. W. Roussin, 0ak Ridge National Laboratory, personal comnunication, September 1977.

5. R. W. Roussin, C. R. Weisbin, J, E. White, N. M. Greene, R. Q. Wright, and J. B. Wright, "CTR Processed Multigroup Cross Section Library for Neutronics Studies," Oak Ridge Nationar. Laboratory report RSIC-37 (July 1977).

6. C. I. Baxman, G. M. Hale, and P. G. Young, "Applied Nuclear Data Research and Development Jenuary 1-March 31, 1976," Los Alamos Sclentific Laboratory report LA-6472-PR (August 1976).

7. C. I. Baxman and P. G. Young, "Applled Nuclear Data Research and Development January 1-March 31 , 1977," Los Alanos Scientific Laboratory report LA-6893-PR (July 1977).

8. E. D. Cashwe11, J. R. Neergaard, W. M. Taylor, and G. D. Turner, "MCN: A Neutron Monte Carlo Code," Los Alamos Scientific Jaboratory report LA-4751 (January 1972). 